\title{
MORPHOLOGICAL CONDITION OF THE COLON WALL IN PATIENTS WITH ACUTE DECOMPENSATED COLONIC OBSTRUCTION
}

\author{
Riabkov I.V. ${ }^{2}$, Pozdnyakov A.A. ${ }^{1}$, Cherdantsev D.V. ${ }^{1}$, Medvedeva N.N. ${ }^{1}$, Popov A.E. ${ }^{1}$, \\ Zhukov E.L.1, Bugriy V.I. ${ }^{2}$. \\ ${ }^{1}$ Krasnoyarsk State Medical University n.a. Professor V.F. Voyno-Yasenetsky, Krasnoyarsk, e-mail: \\ artem.pozdnyakov.doc@gmail.com; \\ ${ }^{2}$ Krasnoyarsk Regional Clinical Oncology Center. n.a. A.I. Kryzhanovskiy, Krasnoyarsk, e-mail: rina-si25@rambler.ru
}

\begin{abstract}
Aims.
The aim of this research is to determine the correlation between the level of abdominal hypertension and morphological conditions of the colon wall in resection zones with low decompensated obturation colonic obstruction in patients with colorectal cancer.

Materials and Methods

A prospective cohort study of 89 patients who were hospitalised urgently and who had surgery due to low decompensated obturative colonic obstruction on the background of colorectal cancer. The morphological structure and intensity of microcirculation of the colonic wall according to laser doppler flowmetry data (LDF) in resection zones was assessed. The level of intra-abdominal pressure (IAP) was measured indirectly through the urinary bladder.
\end{abstract}

Results.

A direct correlation between the level of intra-abdominal hypertension and the severity of obturative colonic obstruction was revealed. At the same time, no serious impairments of blood flow to the colonic wall both distal and proximal of the tumour were found. Despite the high level of pressure in the abdominal cavity, there was not a single case of severe colonic wall ischemia with necrosis of the mucosa. In the case of degree I-II severity of intraabdominal hypertension (according to WSACS), no significant differences in the intensity of tissue perfusion and morphological changes of the intestinal walls in the resection zones were found between patients who underwent scheduled procedures with the application of colonic anastomosis and patients who underwent urgent surgery due to acute obturative colonic obstruction. Progression of intra-abdominal hypertension to degree III was enhanced with the increase of inflammatory changes in the layers of the intestinal wall, and the continuous increase of intraabdominal pressure (degree IV) led to the development of impairments of intraparietal haemodynamics.

Conclusions.

Measurement of intra-abdominal pressure in the preoperative period in patients with acute obturative colonic obstruction can be used as a reliable criterion, which also determines the further surgical approach.

Key words: colorectal cancer, intestinal obstruction, intra-abdominal hypertension, intestinal anastomosis.

\section{INTRODUCTION.}

One of the most important issues in the worldwide morbidity rate is the increase in the rate of malignant neoplasms. In the structure of oncologic morbidity, the leading places are occupied by colon cancer. In 2012, this localization was in the 3rd place by the morbidity rate of cancer (9.7\%) and in the 4th place by the rate of lethality (8.5\%). In Europe, these figures were $13.0 \%$ and $12.2 \%$, respectively, and colorectal cancer moved to the 2 nd place by the morbidity and lethality rate $[1,2]$.

In Russia, in 2008-2013, the average annual increase in the morbidity rate of malignant neoplasms of the colon was $9.9 \%$ [3]. There is an increase in the lethality rate to $13.3 \%$ in patients with malignant neoplasms of the colon $[1,2]$. Presently, in the structure of the malignant oncologic morbidity in Russia, colon cancer occupies the 3rd place and the 2nd place by the lethality rate from malignant neoplasms $[4,5]$.

Many authors highlight the unsatisfactory treatment outcome for colorectal cancer (CRC) in Russia because of the late diagnostics of the neoplasms. Leading specialists in the area of CRC research report that radical therapy is possible only in $40-50 \%$ of cases [6]. 
$\mathrm{CRC}$ is characterized by a long-term symptomless period. For this reason, the first clinical symptom is the clinical picture of CRC complications. According to different sources, around 50$89 \%$ of patients get hospitalized with CRC complications [7].

Occlusion of the colon is the most frequent complication of CRC, which is registered in 30$76.8 \%$ of cases $[8,9]$. It should be mentioned that during the past 50 years, the specific weight of occlusion of the colon increased from $5 \%$ to $24 \%$ in the structure of all the forms of intestine obstruction [3].

The tactics of surgical treatment for patients with malignant bowel obstruction (MBO) with tumor localization in the left colon provokes disputes. The experience of single-step primary reconstructive radical resection on the colon in patients with occlusion of the colon attracts the special interest of surgeons. This is explained by an evident advantage of this technique: lack of repeated interventions, a low level of post-operative disabilities, and reduction of inpatient period. One of the main obstacles for wide implementation of this technique into clinical practice is a high risk of anastomotic dehiscence [10-12].

The most important criterion for the choice of surgical tactics in patients with occlusion of the colon is the degree of its severity. The leading experts treat the severity of the intraabdominal pressure as a factor that determines the severity of pathophysiologic impairments in patients with acute colon obstruction (ACO) [13].

It is especially acute because of the lack of precise criteria for the objective selection of patients for primary reconstructive interventions, which is a serious obstacle for the implementation of this technique into practice.

In the present study, the authors defined the critical levels of the intraabdominal pressure in the postoperative period that could help surgeons to choose patients for safe primary reconstruction.

The study was aimed to perform correlation analysis between the severity of intraabdominal hypertension (IAH) in patients with left colon cancer complicated by a low decompensated occlusion of the colon and the severity of colon wall morphological abnormalities.

\section{MATERIALS AND METHODS.}

It was a prospective cohort study that included patients with CRC with the localization of the tumor in the left colon from the rectosigmoid section to the splenic flexure. The main study entry criterion was a complication of the tumor by a decompensated occlusion of the colon verified by the irrigoscopy results (impossibility to fill the colon above the tumor-induced stenosis). The criteria of exclusion from the study were combined complications of CRC when decompensated occlusion was accompanied by hemorrhage from the deteriorating tumor or perforation, compensated and subcompensated forms of occlusion of the colon, severe associated diseases at the stage of decompensation. Eighty-six patients hospitalized in 2016-2017 met the specified study entry criteria.

Intraabdominal pressure was measured by an indirect method via the bladder. For the 
evaluation of the window of opportunity for the technique of primary reconstruction, the authors performed the intraoperative study of the intensity of the capillary bloodstream in the colon wall by the method of Laser Doppler Flowmetry (LDF) in patients with different degrees of IAH. The control points for LDF were $10 \mathrm{~cm}$ inferior to the obstacle and $10 \mathrm{~cm}$ above the obstacle and proximal to the area of colon resection. The study was performed on the antimesenteric edge of the colon. The control tests were performed in 30 patients after planned surgery without the events of colon obstruction and localization of the tumor in the left colon. The preoperative level of intraabdominal pressure in the control group was $5.5 \pm 0.9 \mathrm{~mm}$. The material for the histological study was fixed in a $10 \%$ solution of formalin; the microscopic study was performed 24 hours after hematoxylin-eosin staining at the magnification of 200.

The statistical analysis of different minor groups was performed with the Kruskal-Wallis test (observational comparison) and the Mann-Whitney U-test (paired comparison). The correlations were evaluated by the method of rank correlation of Spearmen and Kendall.

The mean age of patients included in the study was $67.2 \pm 11.2$ years old. There were 54 men $(60.7 \%)$ aged $66.9 \pm 10.3$ years old, 35 women $(39.3 \%)$ aged $67.7 \pm 12.7$ years old. In 11 patients, the tumor was localized in the projection of the splenic flexion (12\%). In 8 patients (9\%), it was localized in the descending colon, in 61 patients $(69 \%)$ - in the sigmoid colon, and in 9 patients $(10 \%)$ - in the rectosigmoid junction. The lethality rate was $13 \%$ (12 patients).

The present study was approved by the local ethical committee. The aim and methods were explained to the participants who signed the form of the informed consent for the examination, treatment, and publication of the obtained data.

RESULTS. At the admission, the patients had the first measurement of the level of intraabdominal pressure. At this stage, all the patients were divided into groups depending on the onset of the clinical picture of occlusion of the colon (Table 1).

Table 1. The level of intraabdominal pressure at a different time of onset of colon obstruction

\begin{tabular}{|l|c|c|c|c|c|}
\hline $\begin{array}{c}\text { Onset before } \\
\text { admission to the } \\
\text { hospital }\end{array}$ & $\begin{array}{c}\text { Number } \\
\text { of } \\
\text { patients, } \\
\mathbf{N}(\mathbf{M} / \mathbf{F})\end{array}$ & $\begin{array}{c}\text { Age } \\
(\mathbf{m e a n} \pm \text { SD) }\end{array}$ & $\begin{array}{c}\text { Lethality, N } \\
(\boldsymbol{\%})\end{array}$ & $\begin{array}{c}\text { IAP, } \\
\mathbf{m m H g} . \\
(\mathbf{m e a n} \pm \mathbf{S D})\end{array}$ & $\mathbf{P}$ \\
\hline Up to 48 hours & $10(5 / 5)$ & $63.0 \pm 15.0$ & $0(0 \%)$ & $16.5 \pm 4.1$ & \\
\hline $48-72$ hours & $17(12 / 5)$ & $64.9 \pm 10.3$ & $0(0 \%)$ & $20.9 \pm 6.7$ & $=\mathbf{0 . 0 4 9} \dagger$ \\
\hline More than 72 hours & $62(37 / 25)$ & $68.5 \pm 10.7$ & $12(19.4 \%)$ & $29.6 \pm 7.7$ & $<\mathbf{0 . 0 0 1} \dagger$ \\
\hline Total & $89(54 / 35)$ & $67.2 \pm 11.2$ & $12(13.5 \%)$ & $26.5 \pm 8.7$ & $=\mathbf{0 . 0 1 0} *$ \\
\hline
\end{tabular}

* - Kruskal-Wallis test;

$\dagger-$ Mann-Whitney U-test.

After the distribution of patients by the onset of occlusion of the colon, three groups were formed: up to 48 hours, 48 to 72 hours, and more than 72 hours. The Kruskal-Wallis parameter was $\mathrm{p}=0.01$, which indicated significant differences in the levels of intraabdominal pressure between the 
groups. More detailed analysis established a significant level of the increase in the intraabdominal pressure that correlated with the time of the patients' admission to the hospital.

The evaluation of correlations between the onset of occlusion of the colon and the level of intraabdominal pressure revealed a direct correlation with the rank coefficient of Spearmen 0.74 $(\mathrm{p}<0.05)$, the level of gamma-correlation $0.63(\mathrm{p}<0.05)$, and the rank coefficient of Kendall 0.57 $(\mathrm{p}<0.05)$.

Further, the patients were redistributed by groups depending on the initial level of IAH.

The possibility of enteroenteroanastomosis in colorectal surgery is closely associated with the condition of perfusion of the colon wall. This issue is especially acute in patients with occlusion of the colon because the morphological basis for the pathogenesis cascade is provided by the impairment of microcirculation in the colon wall.

The results obtained inferior to the obstacle require additional analysis. There were no significant differences between the control group and the group of patients with the initial level of intraabdominal level of the 1st-2nd degrees of severity (Table 2).

Table 2. The intensity of the capillary bloodstream distal to the tumor

\begin{tabular}{|l|c|c|c|c|c|}
\hline \multicolumn{1}{|c|}{$\begin{array}{c}\text { Intraabdominal } \\
\text { hypertension }\end{array}$} & $\begin{array}{c}\text { Number } \\
\text { of } \\
\text { patients, } \\
\mathbf{N}(\mathbf{M} / \mathbf{F})\end{array}$ & $\begin{array}{c}\text { Age } \\
(\mathbf{m e a n} \pm \mathbf{S D})\end{array}$ & $\begin{array}{c}\text { Lethality, N } \\
(\boldsymbol{\%})\end{array}$ & $\begin{array}{c}\text { Level of } \\
\text { perfusion, } \\
\text { (mean } \pm \mathbf{S D})\end{array}$ & $\mathbf{P}$ \\
\hline $\begin{array}{l}\text { Control group } \\
(\mathrm{Gr})\end{array}$ & $30(13 / 17)$ & $67.0 \pm 11.2$ & $0(0 \%)$ & $17.8 \pm 11.6$ & \\
\hline 1st-2nd degrees (Gr1) & $19(12 / 7)$ & $65.3 \pm 11.4$ & $0(0 \%)$ & $15.2 \pm 5.0$ & $=0.967 \dagger$ \\
\hline 3rd degree (Gr2) & $17(10 / 7)$ & $66.4 \pm 10.5$ & $1(5.9 \%)$ & $28.6 \pm 6.5$ & $<\mathbf{0 . 0 0 1} \dagger$ \\
\hline 4th degree (Gr3) & $53(32 / 21)$ & $68.2 \pm 11.5$ & $11(20.8 \%)$ & $30.7 \pm 9.8$ & $=0.784 \dagger$ \\
\hline Total & $119(67 / 52)$ & $67.0 \pm 11.2$ & $12(10.1 \%)$ & $24.7 \pm 11.4$ & $<\mathbf{0 . 0 0 1 *}$ \\
\hline
\end{tabular}

* - Kruskal-Wallis test;

$\dagger-$ Mann-Whitney U-test.

In patients with IAH of the 3rd-4th degrees of severity, the obtained results did not have significant differences. At the same time, the parameters of intraabdominal pressure were associated with a significant increase in the intensity of the capillary bloodstream inferior to the obstacle nearly by 2 times, which exceeded the results obtained in patients with low or normal intraabdominal pressure.

A possible explanation of the enforcement of perfusion of the capillary bloodstream in the colon wall distal to the occlusion caused by the tumor in patients with severe occlusion of the colon is in the compensatory enforcement of the arterial blood flow because of colon wall ischemia proximal to the tumor. Intraabdominal pressure distal to the tumor is significantly lower. It does not cause the occlusion of intraabdominal vessels, which contributes to the increase in the intensity of blood supply to the colon wall at this level (Figure 1). Besides, an additional factor that influences 
the blood supply to the colon wall is neoangiogenesis in the tumor area that leads to an increase in the blood-feeding of the surrounding tissues.

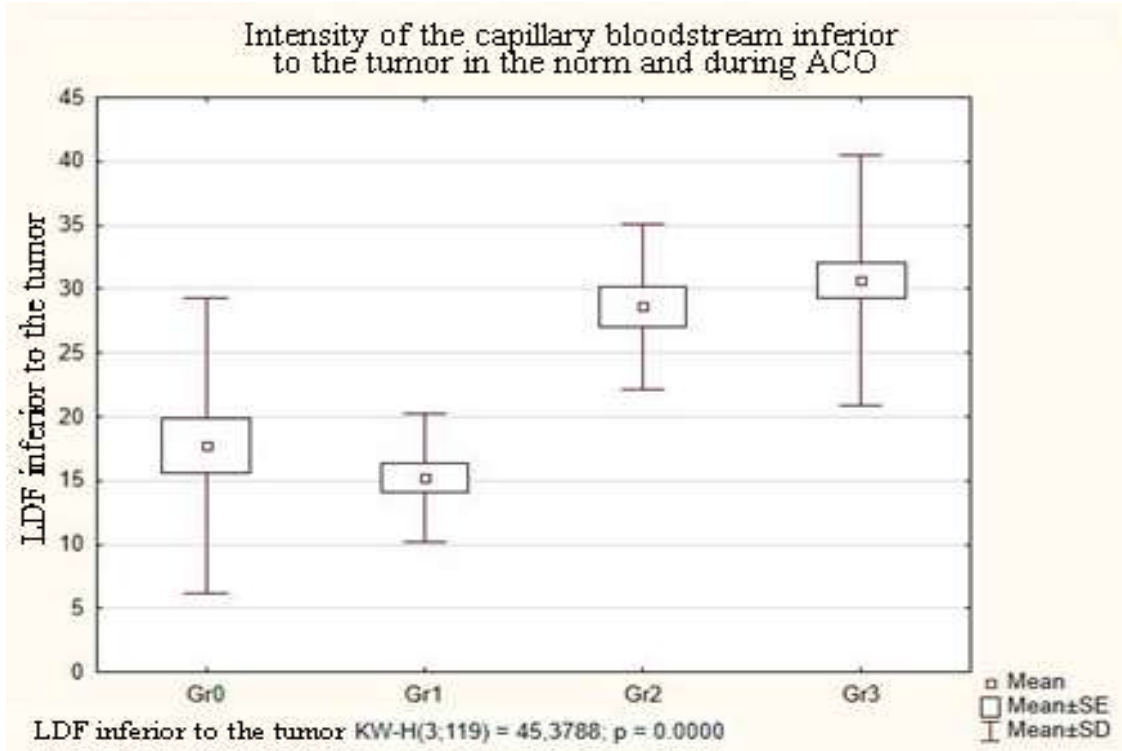

Figure 1. Correlation between the intensity of the capillary bloodstream (LDF) and the level of IAH distal to the tumor

This theory is confirmed by the results of the changes in the colon wall perfusion $10 \mathrm{~cm}$ proximal to the tumor. In this area, the high intensity of the capillary bloodstream was registered that significantly decreased with the increase in the intraabdominal pressure (Table 3). In general, the intensity of microcirculation in the colon wall in patients from the control group and patients with the 1st-2nd degrees of severity of intraabdominal pressure did not differ significantly between each other and were $21.9 \pm 16.9$ and $23.2 \pm 6.6$ perfusion units, respectively $(\mathrm{p}=0.098)$.

It is interesting to mention that a high level of colon wall perfusion in patients with IAH of the 3rd degree (Figure 2) significantly exceeded the control parameter by $25.5 \%(\mathrm{p}=0.042)$, and the values obtained in patients with IAH of the 1 st-2nd degrees - by $18.5 \%(\mathrm{p}=0.036)$.

Thus, the authors did not reveal serious impairments in the colon wall blood supply distal and proximal to the tumor complicated by acute decompensated colon obstruction.

Table 3. The intensity of the capillary bloodstream proximal to the tumor

\begin{tabular}{|l|c|c|c|c|c|}
\hline \multicolumn{1}{|c|}{$\begin{array}{c}\text { Intraabdominal } \\
\text { hypertension }\end{array}$} & $\begin{array}{c}\text { Number } \\
\text { of } \\
\text { patients, } \\
\text { N (M/F) }\end{array}$ & $\begin{array}{c}\text { Age, } \\
(\mathbf{m e a n} \pm \mathbf{S D})\end{array}$ & $\begin{array}{c}\text { Lethality, N } \\
(\boldsymbol{\%})\end{array}$ & $\begin{array}{c}\text { Level of } \\
\text { perfusion } \\
\text { (mean } \pm \text { SD) }\end{array}$ & $\mathbf{P}$ \\
\hline $\begin{array}{l}\text { Control group } \\
(\mathrm{Gr})\end{array}$ & $30(13 / 17)$ & $67.0 \pm 11.2$ & $0(0 \%)$ & $21.9 \pm 16.9$ & \\
\hline 1st-2nd degrees (Gr1) & $19(12 / 7)$ & $65.3 \pm 11.4$ & $0(0 \%)$ & $23.2 \pm 6.6$ & $=0.09 \dagger \dagger$ \\
\hline 3rd degree (Gr2) & $17(10 / 7)$ & $66.4 \pm 10.5$ & $1(5.9 \%)$ & $27.5 \pm 7.4$ & $=\mathbf{0 . 0 3 6} \dagger$ \\
\hline 4th degree (Gr3) & $53(32 / 21)$ & $68.2 \pm 11.5$ & $11(20.8 \%)$ & $18.5 \pm 8.1$ & $<\mathbf{0 . 0 0 1 \dagger}$ \\
\hline Total & $119(67 / 52)$ & $67.0 \pm 11.2$ & $12(10.1 \%)$ & $21.4 \pm 11.1$ & $<\mathbf{0 . 0 0 1 *}$ \\
\hline
\end{tabular}

* - Kruskal-Wallis test; 


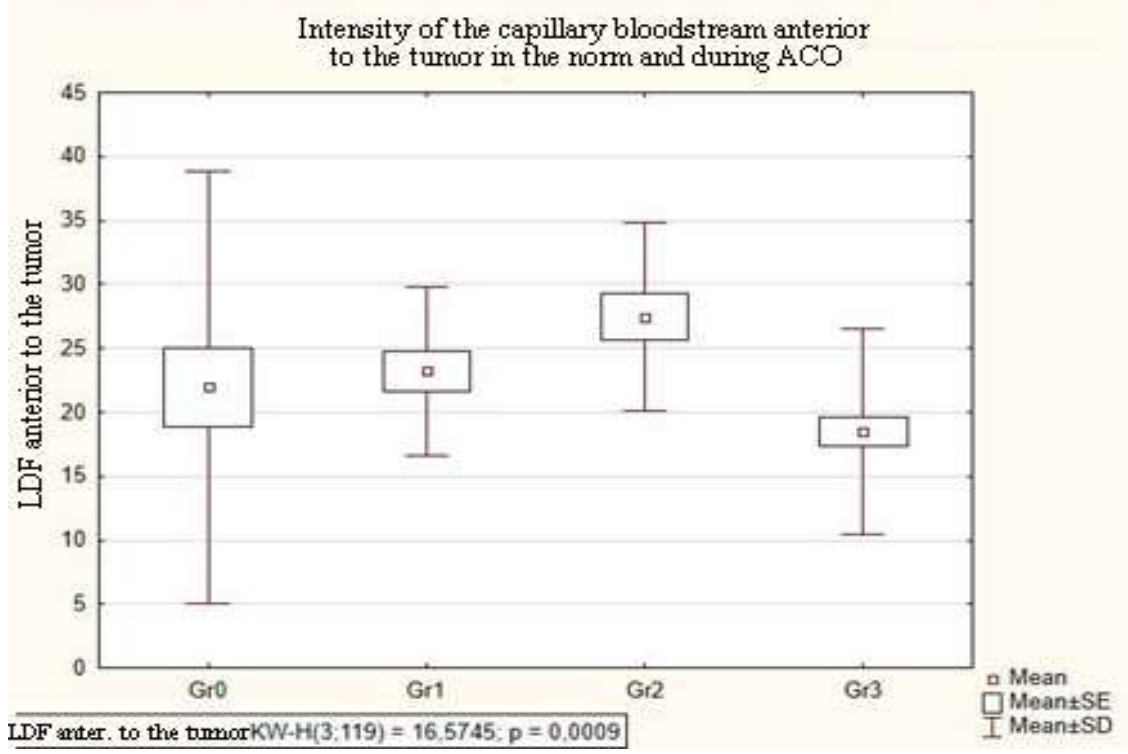

Figure 2. Correlation between the intensity of the capillary bloodstream $(L D F)$ and the level of IAH proximal to the tumor

The intensity of perfusion in the colon wall tissues proximal to the resection (at the level of the planned enteroenteroanastomosis) plays an important role. At this level, the authors registered lower values, which can also be explained by the theory of high levels of perfusion in the tumor area due to neoangiogenesis.

It should be mentioned that the authors did not reveal significant differences in the level of tissue perfusion in patients with IAH of the 1st-2nd and 3rd degrees of severity in comparison with the control group (Table 4). Only in patients with the 4th degree of severity of intraabdominal pressure, a significant decrease in the level of perfusion by $8.8 \%(p=0.029)$ was observed in comparison with the control group (Figure 3).

Table 4. The intensity of the capillary bloodstream in the proximal area of the resection.

\begin{tabular}{|l|c|c|c|c|c|}
\hline \multicolumn{1}{|c|}{$\begin{array}{c}\text { Intraabdominal } \\
\text { hypertension }\end{array}$} & $\begin{array}{c}\text { Number } \\
\text { of } \\
\text { patients, } \\
\mathbf{N}(\mathbf{M} / \mathbf{F})\end{array}$ & $\begin{array}{c}\text { Age } \\
(\mathbf{m e a n} \pm \mathbf{S D})\end{array}$ & $\begin{array}{c}\text { Lethality, N } \\
(\boldsymbol{\%})\end{array}$ & $\begin{array}{c}\text { Level of } \\
\text { perfusion, } \\
\text { (mean } \pm \text { SD) }\end{array}$ & $\mathbf{P}$ \\
\hline $\begin{array}{l}\text { Control group } \\
(\mathrm{Gr})\end{array}$ & $30(13 / 17)$ & $67.0 \pm 11.2$ & $0(0 \%)$ & $15.9 \pm 6.3$ & \\
\hline 1st-2nd degrees (Gr1) & $19(12 / 7)$ & $65.3 \pm 11.4$ & $0(0 \%)$ & $15.5 \pm 4.6$ & $=0.659 \dagger$ \\
\hline 3rd degree (Gr2) & $17(10 / 7)$ & $66.4 \pm 10.5$ & $1(5.9 \%)$ & $16.2 \pm 4.5$ & $=0.680 \dagger$ \\
\hline 4th degree (Gr3) & $53(32 / 21)$ & $68.2 \pm 11.5$ & $11(20.8 \%)$ & $12.7 \pm 4.7$ & $=\mathbf{0 . 0 0 4} \dagger$ \\
\hline Total & $119(67 / 52)$ & $67.0 \pm 11.2$ & $12(10.1 \%)$ & $14.5 \pm 5.3$ & $=\mathbf{0 . 0 0 5 *}$ \\
\hline
\end{tabular}

* - Kruskal-Wallis test;

$\dagger-$ Mann-Whitney U-test.

The analysis of the results of the study of colon wall perfusion in patients with acute colon obstruction did not reveal severe microcirculation impairments in the colon wall that would provide 
a contraindication for the primary anastomosis in patients with the 1st-2nd degrees of severity of IAH. A significant decrease in the levels of perfusion of the colon wall was registered only in patients with an increase in the intraabdominal pressure above $25 \mathrm{mmHg}$. At the same time, it should be taken into account that the obtained results were registered intraoperatively after a wide laparotomy and factual resolution of intraoperative hypertension after possible paralytic dilation of capillaries.

This suggestion provided grounds for the morphological study of the specimens of the colon wall proximal to the resection for the identification of the presence of true trophic impairments of tissues and tissue risk factors for anastomotic dehiscence. Such factors included the signs of intraparietal hemodynamics (paresis of arterioles and venules with vascular stasis and tissue edema) and signs of inflammatory changes in the colon wall (more or less expressed leukocytic infiltration of the colon wall layers).

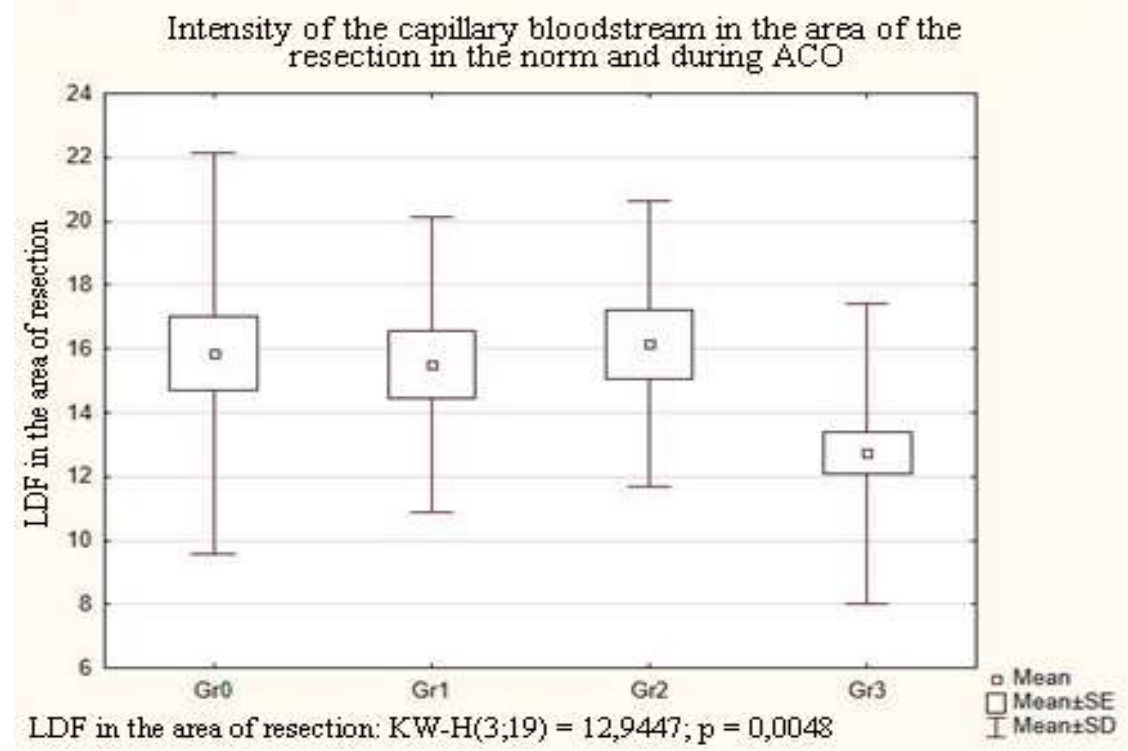

Figure 3. Correlation between the intensity of the capillary bloodstream (LDF) and the level of IAH proximal to the resection

The study results in the group of patients with IAH of the 1st-2nd degrees revealed moderate mucosal edema, regular blood filling of the mucosal layer, its moderate leukocytic infiltration primarily with segmental leukocytes (Figure 4A). In the submucosal layer, there was an increase in edema. Submucosal vessels were filled with blood unevenly. Poor histiocytic infiltration without cellular clusters was observed. The muscular layer had a regular structure, which indirectly indicated the lack of severe dilation and toxic effect on the colon wall. The serous membrane had mild edema with moderate vascular congestion and poorly expressed histiocytic infiltration (Figure 4B).

The morphological picture of the colon wall in patients with the 3rd degree of IAH was characterized by the progression of inflammatory alterations, edema and polymorphocellular infiltration of the colon wall layers (Figure 4 C, D). In the majority of specimens, edema and lack of blood supply to vessels of the serous membrane with foci of congested arterioles were observed. 
The formation of different-caliber histiocytic infiltrates with moderate inclusion of segmented leukocytes was revealed. The submucosal layer had moderate edema and emptiness of vessels. Minor vessels had a high leukocyte count. Numerous small focal infiltrates that consisted of segmented leukocytes, histiocytes, and lymphocytes were observed (Figure 4C).

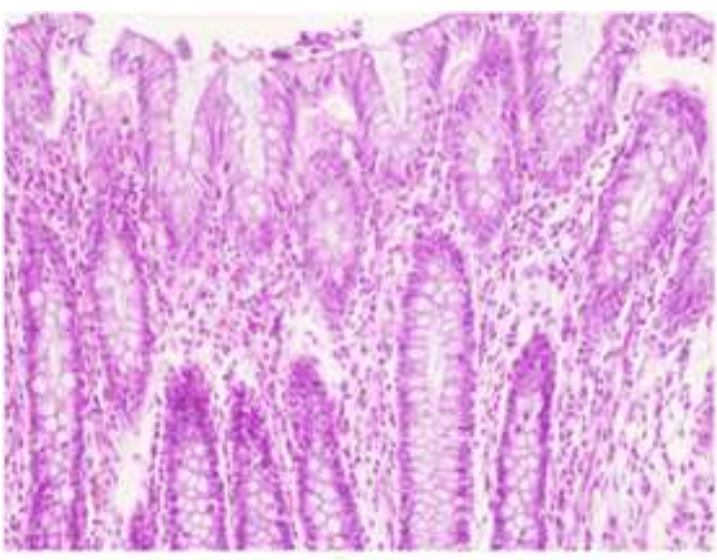

A

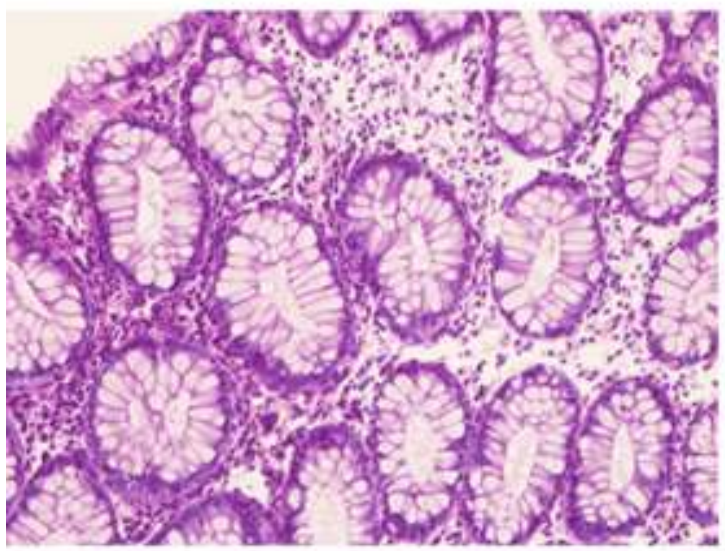

$\mathrm{C}$

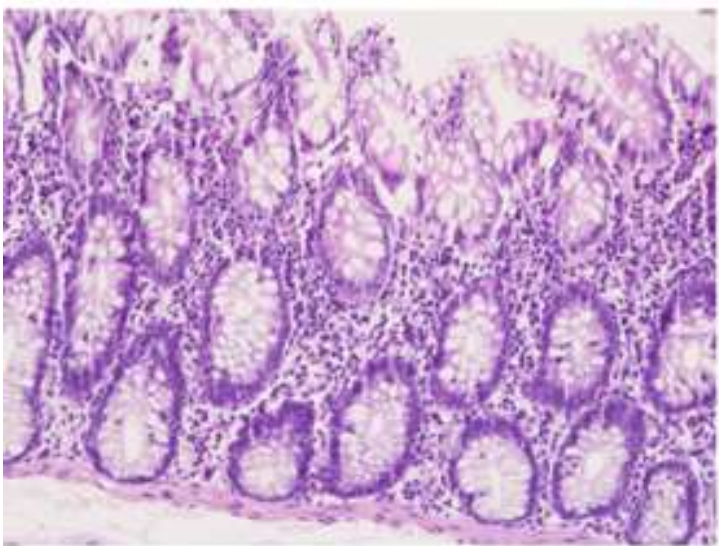

$\mathrm{E}$

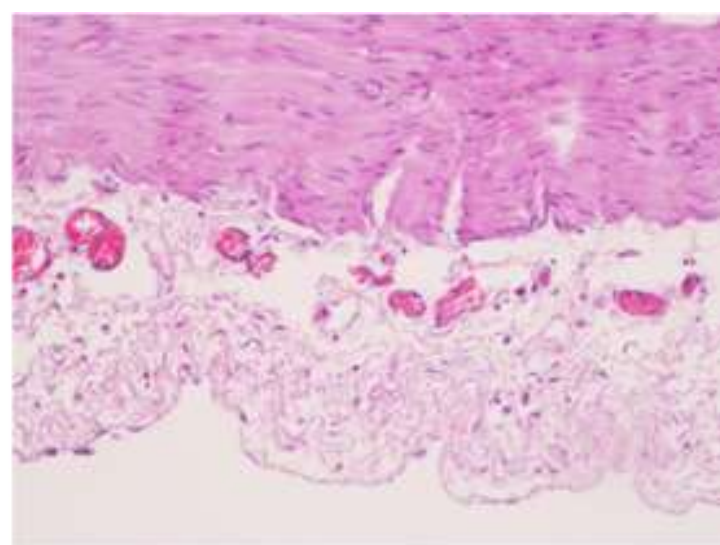

B

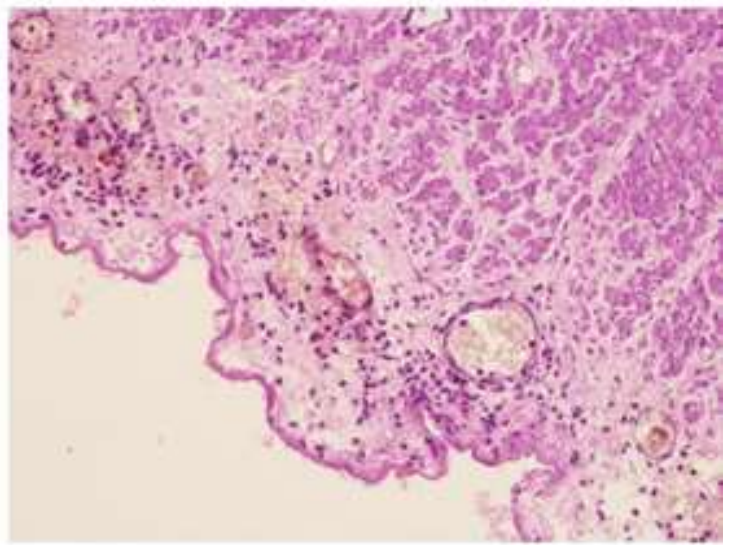

$\mathrm{D}$

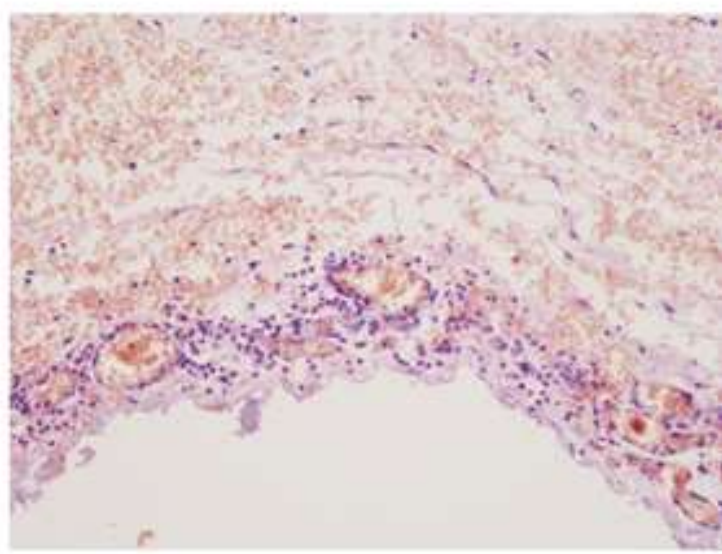

$\mathrm{F}$

Figure 4. Specimen of the colon wall proximal to the resection in patients with acute colon obstruction. Hematoxylin-eosin staining. Magnification X 200:

A, $B$ - mild, 1st-2nd degrees of IAH by WSACS

$C, D$ - moderate, $3 r d$ degree of IAH by WSACS;

$E, F$ - severe, 4th degree of IAH by WSACS; 
The muscular layer had edematous foci with leukocyte clusters in the connective tissue interlayers that led to the development of leukocytic infiltrates. Moderate edema of the serous layer was observed. The vascular bed of the subserous layer was characterized by erythrocyte stasis with a high leukocyte count along the edge of the vascular wall (Figure 4D).

The most severe alterations in the colon wall were registered in patients with acute colon obstruction and the 4th degree of IAH. It should be mentioned that despite high pressure in the abdominal cavity, there were no cases of severe colon wall ischemia with mucous necrosis registered. The morphological picture of patients from this group had expressed edema with vascular congestion, significant infiltration with lymphohistiocytic cells with clusters of segmented leukocytes (Figure 4E), submucosal edema with congestion of arteries, and venous stasis. Leukocyte margination in the vessels was registered.

The muscular layer had expressed infiltration of segmented leukocytes and significant edema of the serous layer (Figure 4F) with lymphohistiocytic infiltrate with erythrocyte stasis and leukocyte margination in the vessels.

The morphological analysis showed that the most favorable picture with minimal alterations (moderate lymphohistiocytic infiltration of the serous and submucosal layers) was observed only in patients with moderate intraabdominal pressure (1st-2nd degrees of IAH by WSACS) associated with acute colon obstruction. Progressing of IAH of the 2nd degree is associated with the enhancement of inflammatory alterations in the colon wall layers. A further increase in the intraabdominal pressure leads to the impairments of intraparietal hemodynamics. However, it should be mentioned that these disturbances in the colon wall blood supply did not lead to necrobiotic alterations.

\section{CONCLUSIONS.}

The study on the correlation of intraabdominal hypertension in patients with acute colon obstruction revealed a significant direct correlation between this parameter and the degree of severity of the occlusion of the colon. This correlation is proved by the evaluation of the degree of severity based on the criterion of the disease onset, X-ray images, and SAPS scale. Thus, the measurement of intraoperative pressure in the postoperative period in patients with acute colon obstruction can be used as a reliable criterion that can determine further surgical tactics.

Based on the results of the performed studies, the authors proposed to classify occlusion of the colon with the initial level of IAH of the 1st-2nd degrees by WSACS as a mild degree of severity, IAH of the 3rd degree by WSACS - as moderate, and IAH of the 4th degree by WSACS as severe.

Such distribution by the degrees of severity also agrees with the expression of intraparietal impairments in the microcirculation and should be considered in the planning of surgery for patients with acute colon obstruction. 
The results of the study of the perfusion of colon wall by LDF and the morphological study of colon tissues did not reveal any significant differences in the intensity of tissue perfusion and morphological alterations in the colon wall in the area of resection between patients who had planned surgery with colonic anastomosis and patients who had urgent surgery for acute colon obstruction when they had the 1st-2nd degrees of intraabdominal hypertension. This data is important to know in the prognosis of postoperative complications in the area of anastomosis and provides grounds for safe primary reconstruction.

\section{FINANCIAL SUPPORT AND SPONSORSHIP}

Nil.

\section{CONFLICTS OF INTEREST}

The authors declare no conflict of interest

\section{SUPPLEMENTARY DATA (DOI)}

\section{REFERENCES}

1. Aksel' E.M., Barmina N.M. Colorectal cancer (morbidity, mortality, socio-economic damage) [Kolorektal'nyi rak (zabolevaemost', smertnost', sotsial'no-ekonomicheskii ushcherb)]. Russian Journal of Oncology - Rossiiskii onkologicheskii zhurnal, 2013, no. 6, pp. 40-46.

2. Stewart B., Wild C.P. World cancer report 2014. Lyon, International Agency for Research on Cancer, 2014, $630 \mathrm{p}$.

3. Petrova G.V., Kaprin A.D., Gretsova O.P. et al. Malignant neoplasms in Russia: review of statistical information for 1999-2013 [Zlokachestvennye novoobrazovaniia v Rossii: obzor statisticheskoi informatsii za 1999-2013 gg.], Moscow, M.: MNIOI im. P.A. Gertsena - filial FGBU «NMIRTs» Minzdrava Rossii, 2015, 511 p.

4. Davydov M.I., Aksel' E.M. Mortality of Russian and CIS population from malignant neoplasms in 2007 [Smertnost' naseleniia Rossii i stran SNG ot zlokachestvennykh novoobrazovanii v 2007 g.], Journal of N.N. Blokhin - Vestnik RONTs im. N.N. Blokhina RAMN RCRC, 2009, vol. 20, no. 3, pp. 91-122.

5. Denisenko V.L., Gain Iu.M. Complications of colorectal cancer: problems and prospects [Oslozhneniia kolorektal'nogo raka: problemy i perspektivy]. Novosti khirurgii - Novosti Khirurgii, 2011, vol. 19, no. 1, pp. 103-111

6. Vorob'ev G.I., Zhuchenko A.P., Filon A.F. et al. The noncomplicated colon cancer treatment [Klinicheskoe znachenie mul'tispiral'noi komp'iuternotomograficheskoi koronarografii]. Pirogov Russian Journal of Surgery - Khirurgiya. Zhurnal imeni N.I. Pirogova, 2010, no. 7, pp. 10-14.

7. Knysh V.I., Cherkes V.L., Anan'ev V.S. Ways to improve colorectal cancer outcomes [Puti uluchsheniia rezul'tatov lecheniia kolorektal'nogo raka]. Russian Journal of Oncology - Rossiiskii Onkologicheskii Zhurnal, 2001, no. 5, pp. 25-27.

8. Sazhin V.P., Gostkin P.A., Avdovenko A.L. et al. Treatment of obturatory intestinal obstruction 
[Lechenie obturatsionnoi kishechnoi neprokhodimosti]. International Surgical Congress "Current Problems of Modern Surgery" [Mezhdunarodnyi khirurgicheskii kongress «Aktual'nye problemy sovremennoi khirurgii»]. Moscow, 2003, pp. 119.

9. Liu Z., Kang L., Li C. et al. Meta-analysis of complications of colonic stenting versus emergency surgery for acute left-sided malignant colonic obstruction. Surgical laparoscopy, endoscopy \& percutaneous techniques, 2014, vol. 24, no 1, pp. 73-79, doi 10.1097/sle.0000000000000030.

10. Beliaev A.M., Surov D.A., Sementsov K.V. Single-stage operations at left-hand thick-eye obstruction [Odnoetapnye operatsii pri levostoronnei tolstokishechnoi neprokhodimosti]. Grekov's Bulletin of Surgery - Vestnik khirurgii im. I.I. Grekova, 2010, vol. 169, no. 4, pp. 36-38.

11. Vainer Iu.S., Atamanov K.V., Veriatin Ia.A. Peculiarities of angioarchitectonics of the small intestine at various methods of cut its wall [Osobennosti angioarkhitektoniki tonkoi kishki pri razlichnykh sposobakh peresecheniia ee stenki]. Siberian Medical Review - Sibirskoe meditsinskoe obozrenie, 2017, no. 3, pp. 56-60, doi: 10.20333/2500136-2017-3-56-60.

12. Edino S.T., Mohammed A.Z., Anumah M. Intraoperative colonic lavage in emergency surgical treatment of left-sided large bowel lesions. Tropical Doctor, 2005, vol. 35, no 1, pp. 37-38, doi $10.1258 / 0049475053001741$.

13. Carlotti A.P., Carvalho W.B. Abdominal compartment syndrome: A review. Pediatric Critical Care Medicine, 2009, vol. 10, no 1, pp. 115-120, doi 10.1097/pcc.0b013e31819371b2. 